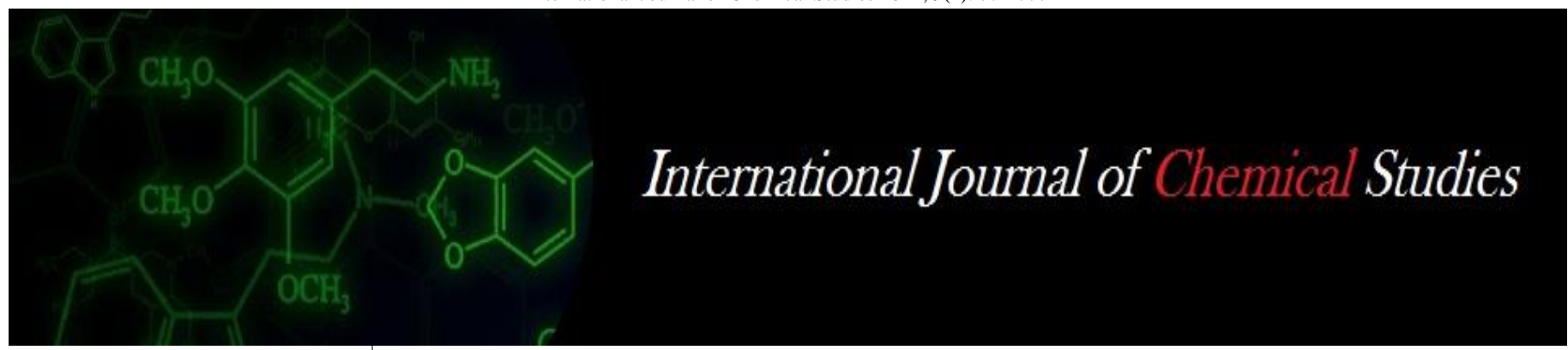

P-ISSN: 2349-8528

E-ISSN: 2321-4902

www.chemijournal.com

IJCS 2021; 9(1): 774-777

(C) 2021 IJCS

Received: 18-10-2020

Accepted: 27-11-2020

\section{RC Patel}

P.G. Scholar, College of

Horticulture, S. D. Agricultural

University, Jagudan, Mehsana,

Gujarat, India

AJ Patel

P.G. Scholar, College of

Horticulture, S. D. Agricultural

University, Jagudan, Mehsana,

Gujarat, India

\section{GS Patel}

Associate Professor, College of Horticulture, S. D. Agricultural University, Jagudan, Mehsana, Gujarat, India

\section{DM Thakor}

Associate Professor, College of Horticulture, S. D. Agricultural University, Jagudan, Mehsana, Gujarat, India

\section{Mukeshkumar}

Assistant Professor, College of Horticulture, S. D. Agricultural University, Jagudan, Mehsana, Gujarat, India
Corresponding Author: RC Patel

P.G. Scholar, College of Horticulture, S. D. Agricultural University, Jagudan, Mehsana, Gujarat, India

\section{Effect of different micronutrients and stage of their application on quality of cabbage (Brassica oleracea var. capitata)}

\author{
RC Patel, AJ Patel, GS Patel, DM Thakor and Mukeshkumar
}

DOI: https://doi.org/10.22271/chemi.2021.v9.i1k.11318

\begin{abstract}
A field experiment was conducted at College Farm, College of Horticulture, Sardarkrushinagar Dantiwada Agricultural University, Jagudan, Gujarat in the rabi season of the year 2017-18 to study the Effect of different micronutrients and stage of their application on growth, yield and quality of cabbage (Brassica oleracea var. capitata). The experiment was laid out in Randomized Block Design with Factorial concept comprising of two factors. The first factor was stages of micronutrient application (S) i.e. s1 - at seedling stage (15 DAS), s2 - after transplanting (20 \& 35 DAT) and s3 - at seedling stage (15 DAS) and after transplanting (20 \& 35 DAT) and the second factor was micronutrients with eight levels viz., $\mathrm{m}_{0}-\mathrm{Zn} 0 \mathrm{ppm}+\mathrm{B} 0 \mathrm{ppm}+\mathrm{Mo} 0 \mathrm{ppm}, \mathrm{m}_{1}-\mathrm{Zn} 0 \mathrm{ppm}+\mathrm{B} 0 \mathrm{ppm}+\mathrm{Mo} 50 \mathrm{ppm}, \mathrm{m}_{2}-\mathrm{Zn} 0 \mathrm{ppm}+\mathrm{B}$ $200 \mathrm{ppm}+\mathrm{Mo} 0 \mathrm{ppm}, \mathrm{m}_{3}-\mathrm{Zn} 0 \mathrm{ppm}+\mathrm{B} 200 \mathrm{ppm}+\mathrm{Mo} 50 \mathrm{ppm}, \mathrm{m}_{4}-\mathrm{Zn} 1000 \mathrm{ppm}+\mathrm{B} 0 \mathrm{ppm}+\mathrm{Mo} 0$ ppm, $\mathrm{m}_{5}-\mathrm{Zn} 1000$ ppm + B 0 ppm + Mo 50 ppm, m6 - Zn 1000 ppm + B 200 ppm + Mo 0 ppm, m7 - Zn $1000 \mathrm{ppm}+$ B $200 \mathrm{ppm}+$ Mo $50 \mathrm{ppm}$. The treatments were replicated thrice. The individual effect of micronutrient application at different stages as well as their interaction effect on quality of cabbage cv. 'Golden Acre' was recorded. The results indicates that micronutrient application at seedling stage (15 DAS) and after transplanting (20 \& 35 DAT) gave maximum diameter of head, volume of head and chlorophyll content (a, b \& total) was observed higher due to this treatment. Higher dose of micronutrient application was found i.e. @ Zn 1000 ppm + B 200 ppm + Mo 50 ppm superior for quality parameters i.e. diameter of head, volume of head and chlorophyll content ( $\mathrm{a}, \mathrm{b} \&$ total). The interaction effect of stage of micronutrient application and micronutrients were found not significant for all parameters of quality. Thus from the present investigation it could be concluded that for successful cultivation of cabbage, micronutrient should spray at seedling stage (15 DAS) and (20 \& 35 DAT) for getting good quality. Micronutrients should applied @ Zn 1000 ppm + B 200 ppm + Mo 50 ppm for same.
\end{abstract}

Keywords: Cabbage, micronutrients, quality

\section{Introduction}

Cabbage (Brassica oleracea var. capitata) is one of the important leafy vegetable crop and used as salad, cooked, pickling as well as dehydrated vegetable. The word "Cabbage" is derived from the French word "coboche" mean head. The cabbage belongs to cruciferae family. It is grown in kitchen and truck gardens. It is mostly employed as culinary and dietry article which is used alone or mixed with potatoes for vegetable purpose. It is also used for feeding stock of chicken. The "Sauerkraut" is favorite food in Russia, Germany and U.S.A. which is made by fermenting chopped, ground or sliced cabbage in its juice with little salt added to it and from the nutritional point of view, it ranks very high. The particular flavor in the cabbage head is due to the glycoside 'sinigrin' which contain sulphur also. The cabbage head is rich source of vitamin A, B, C and also contains minerals. It has cooling effect and helps in preventing constipation, increase appetite, speed up digestion and very useful for patients of diabetes.

Cabbage is a high feeder of nutrients. Therefore, the judicious application of macro and micronutrients along with required dose of organic manures is essential for getting high yield of quality produce. The foliar application of micronutrients reduces the two cost owing to the lesser quantities required nutrients and better absorption through the foliage. In cultivation of cabbage, nutrition is one of the most important factor which governs the productivity and quality of cabbage. 
It is reported that, the use of micro-nutrients plays an important role in enhancing the translocation of carbohydrates from the site of synthesis to the storage organ and also helps in increasing yield and quality of cabbage. (Jany et al. 2008) [5].

Micronutrient can be restored, maintained and sustained by three procedures eg. Addition of organic residues from plant and animal sources, strengthening the soil biological process and use of synthetic micronutrients and soil amendments as per needs. The availability of the essential micronutrients to plants is often poorly related to the total quantity of the particular element in the soil. Iron and zinc are the most abundant metal to be found in living organisms, where it plays a major structural, catalytic and co-catalytic role in enzyme.

Zinc are one of the essential micronutrient in plants is necessary for plant growth and development and involved in many enzymatic activities and IAA formation to increase flower number and fruit set. However excessive $\mathrm{Zn}$ in plants can profoundly affect normal ionic homeostatic systems by interfering with the uptake, transport, osmotic and regulation of essential ions and results in the disruption of metabolic processes such as transpiration, photosynthesis and enzyme activities related to metabolism (Sainju et al. 2003) ${ }^{[10]}$. Zinc plays a fundamental role in several critical functions in the cell such as protein metabolism, gene expression, structural and functional integrity of bio-membranes and photosynthetic carbon metabolism (Cakmak 2000) ${ }^{[1]}$. In case of zinc deficiency in plants terminal leaves are small, bud formation is poor and leaves have dead areas.

Boron is an essential micronutrient which plays a key role in a diverse range of plant functions including cell wall formation and stability maintenance of structural and functional integrity of biological membranes, movement of sugar or energy into growing parts of plants, pollination, seed set and adequate boron is also required for effective nitrogen fixation in plants (Hakala et al. 2006) ${ }^{[3]}$.

Molybdenum is taken up by plants as molybdate ions. It stimulates the photosynthesis and increase the metabolic process (Chattopadhyay and Mukhopadhyay, 2003) ${ }^{[2]}$. It enables plants to make use of nitrogen without it plants cannot transform nitrate nitrogen to amino acids and legumes cannot fix atmospheric nitrogen. Deficiency of molybdenum can occur in alluvial soils. Visual symptoms due to Mo deficiency include mottling, scorching, wilting and frequent cupping of older and middle leaves. Malformation or death of the growing point was also recorded (Hewitt and Bolle-jones, 1952) $)^{[4]}$.

\section{Materials and Methods}

The experiment was carried out in open field condition during rabi season, 2017 at field of College of Horticulture, S. D. Agricultural University, Jagudan, Dist. - Mehsana (Gujarat). Variety Golden Acre of cabbage was taken under investigation, the seeds of this variety were procured from IARI, Regional Station, Katrain (KulluValley).

Micronutrients were the commercial preparation available in the market and it was in powder form. The application of zinc, boron and molybdenum as foliar spray of zinc sulphate, borax and ammonium molybdate, respectively was used and sprayed on foliage in aqueous form by using fresh solution at each spray. For preparation of 1000 ppm Zn, 200 ppm B and
$50 \mathrm{ppm}$ Mo weighed $4.76 \mathrm{~g}$ of zinc sulphate hepta hydrate, $1.82 \mathrm{~g}$ borax and $0.1 \mathrm{~g}$ ammonium molybdate, respectively dissolved separately in one litre water. Spraying was done with micro sprayer and the leaves were wetted thoroughly with a fine mist.

The experiment was laid out in Randomized Block Design with factorial concept (FRBD) keeping two factor viz., stage of application of micronutrients and micronutrients, the first factor with three stage of application of micronutrients i.e. at seedling stage (15 DAS), after transplanting (20 \& 35 DAT), at seedling stage (15 DAS) and after transplanting (20 \& 35 DAT) while second factor i.e. micronutrients with eight levels thus, making twenty four treatment combinations.

\section{Diameter of head}

The diameter of head was measured in centimeter with the help of Digital Vernier Calipers (AK962EV) at the time of harvesting of selected plants and average diameter of head was worked out.

\section{Volume of head}

The volume of head was measured in cubic centimeter by water displacement method. Water was removed from container by sinking individual head in it and this removed water was measured in measuring cylinder and average volume of head was worked out.

\section{Estimation of a, b \& total chlorophyll at 45 DAT}

The leaves of selected plants analysed for estimation of $a, b$ and total chlorophyll $(\mathrm{mg} / 100 \mathrm{~g})$ as per method suggested by Sadasivam and Manickam (1997) ${ }^{[9]}$.

\section{Results and Discussion \\ Quality Parameters}

Effect of stage of micronutrient application and micronutrients on diameter of head $(\mathrm{cm})$ and volume of head $\left(\mathrm{cm}^{3}\right)$

The analysed data pointed that micronutrient application at seedling stage and after transplanting $\left(\mathrm{s}_{3}\right)$ recorded significantly maximum head diameter $(11.95 \mathrm{~cm})$ and volume of head $\left(832.24 \mathrm{~cm}^{3}\right)$, though, it was statistically at par with treatment $\left(\mathrm{s}_{2}\right)$. Whereas, minimum head diameter $(11.10 \mathrm{~cm})$ and volume of head $\left(702.23 \mathrm{~cm}^{3}\right)$ was recorded with micronutrient application at seedling stage $\left(\mathrm{s}_{1}\right)$.

Perusal of data also showed that foliar application of micronutrients Zn 1000 ppm + B 200 ppm + Mo 50 ppm $\left(\mathrm{m}_{7}\right)$ recorded significantly maximum head diameter $(12.96 \mathrm{~cm})$ and volume of head $\left(842.42 \mathrm{~cm}^{3}\right)$. The treatment $\mathrm{m}_{7}$ was found statistically at par with treatment $m_{6}$ and $m_{5}$. While, the minimum head diameter $(9.80 \mathrm{~cm})$ and volume of head $\left(694.91 \mathrm{~cm}^{3}\right)$ found with no application of micronutrients treatment $\left(\mathrm{m}_{0}\right)$. The marked improvement in volume of head by application of zinc might be due to the improved physiological activities like photosynthesis during which food is manufactured by the plant, translocation of assimilates form leaves to head and their storage in head for which zinc was responsible factor. Similar results were also reported by Kotecha et al. (2011) ${ }^{[6]}$ in cabbage and Lashkari et al. (2007) [7] in cauliflower.

The interaction effect between stage of micronutrient application and micronutrients was found not significant for head diameter $(\mathrm{cm})$ and volume of head $\left(\mathrm{cm}^{3}\right)$. 
Table 1: Effect of stage of micronutrient application and micronutrients on diameter of head $(\mathrm{cm})$ and volume of head $\left(\mathrm{cm}^{3}\right)$

\begin{tabular}{|c|c|c|}
\hline Treatment & Diameter of head $(\mathrm{cm})$ & Volume of head $\left(\mathrm{cm}^{3}\right)$ \\
\hline \multicolumn{3}{|c|}{ Factor A : Micronutrients (M) } \\
\hline $\mathrm{m}_{0}: \mathrm{Zn} 0+\mathrm{B} 0+\mathrm{Mo} 0$ & 9.80 & 694.91 \\
\hline $\mathrm{m}_{1}: \mathrm{Zn} 0+\mathrm{B} 0+\mathrm{Mo} 50$ & 10.26 & 719.31 \\
\hline $\mathrm{m}_{2}: \mathrm{Zn} 0+\mathrm{B} 200+\mathrm{Mo} 0$ & 10.75 & 729.47 \\
\hline $\mathrm{m}_{3}: \mathrm{Zn} 0+\mathrm{B} 200+$ Mo 50 & 12.61 & 753.89 \\
\hline $\mathrm{m}_{4}: \mathrm{Zn} 1000+\mathrm{B} 0+\mathrm{Mo} 0$ & 11.57 & 741.73 \\
\hline $\mathrm{m}_{5}: \mathrm{Zn} 1000+\mathrm{B} 0+\mathrm{Mo} 50$ & 12.58 & 807.67 \\
\hline m6: Zn $1000+$ B $200+$ Mo 0 & 12.63 & 822.18 \\
\hline$m_{7}:$ Zn $1000+$ B $200+$ Mo 50 & 12.96 & 842.42 \\
\hline S.Em. \pm & 0.17 & 12.73 \\
\hline C.D. at $5 \%$ & 0.49 & 36.23 \\
\hline \multicolumn{3}{|c|}{ Factor B : Stage of micronutrients application $(\mathrm{S})$} \\
\hline s1: At seedling stage (15 DAS) & 11.10 & 702.23 \\
\hline s2: After transplanting stage $(20 \& 35$ DAT $)$ & 11.89 & 757.38 \\
\hline S3: At seedling stage (15 DAS) and After transplanting stage (20 \& 35 DAT) & 11.95 & 832.24 \\
\hline S.Em. \pm & 0.11 & 7.79 \\
\hline C.D. at $5 \%$ & 0.30 & 22.18 \\
\hline \multicolumn{3}{|c|}{ Interaction : $(\mathbf{S} \times \mathrm{M})$} \\
\hline S.Em.土 & 0.30 & 22.04 \\
\hline C.D. at $5 \%$ & NS & NS \\
\hline C. V. $(\%)$ & 4.42 & 5.00 \\
\hline
\end{tabular}

Effect of stage of micronutrient application and micronutrients on chlorophyll a, b and total chlorophyll (mg/g) at 45 DAT

Data revealed that the influence of different stage of micronutrient application with respect to a, b and total chlorophyll (mg/g) at 45 DAT was found significant. Significantly maximum chlorophyll a $(0.255 \mathrm{mg} / \mathrm{g})$, chlorophyll b $(0.207 \mathrm{mg} / \mathrm{g})$ and total chlorophyll $(0.474 \mathrm{mg} / \mathrm{g})$ at 45 DAT were found with application of micronutrient at seedling stage and after transplanting $\left(s_{3}\right)$. Micronutrients involves in different physiological process like enzyme activation, electron transport, chlorophyll formation and stomatal regulation etc. These results were in conformity with the results of Mehraj et al. (2015) ${ }^{[8]}$ okra.

It was also recorded that maximum chlorophyll a $(0.276$ $\mathrm{mg} / \mathrm{g})$, chlorophyll b $(0.295 \mathrm{mg} / \mathrm{g})$ and chlorophyll total $(0.637 \mathrm{mg} / \mathrm{g})$ at $45 \mathrm{DAT}$ was found in the treatment foliar application of micronutrient Zn 1000 ppm + B 200 ppm + Mo
$50 \mathrm{ppm}\left(\mathrm{m}_{7}\right)$. Whereas, the minimum a, b and total chlorophyll $(\mathrm{mg} / \mathrm{g})$ was observed in no application of micronutrients treatment $\left(\mathrm{m}_{0}\right)$.

The increase in the values of chlorophyll content may be due to the availability of zinc which aids plant growth hormone and enzyme system, hence it is necessary for chlorophyll formation likewise iron acts as an oxygen carrier and involved in cell division and growth which might have promotes chlorophyll formation. The similar results were also reported by Kotecha et al. (2011) ${ }^{[6]}$ who reported that, the combined application of zinc sulphate $0.5 \%$ and gibberellic acid 100 ppm were found effective in increasing chlorophyll content in cabbage.

The interaction between different stage of micronutrient application and micronutrients exhibited not significant difference with respect to chlorophyll a, b and total chlorophyll at 45 DAT.

Table 2: Effect of stage of micronutrient application and micronutrients on chlorophyll a, b and total chlorophyll (mg/g) at 45 DAT

\begin{tabular}{|c|c|c|c|}
\hline Treatment & Chlorophyll a & Chlorophyll b & Chlorophyll total \\
\hline \multicolumn{4}{|c|}{ Factor A : Micronutrients (M) } \\
\hline $\mathrm{m}_{0}: \mathrm{Zn} 0+\mathrm{B} 0+\mathrm{Mo} 0$ & 0.178 & 0.134 & 0.318 \\
\hline $\mathrm{m}_{1}: \mathrm{Zn} 0+\mathrm{B} 0+\mathrm{Mo} 50$ & 0.184 & 0.138 & 0.339 \\
\hline $\mathrm{m}_{2}: \mathrm{Zn} 0+\mathrm{B} 200+\mathrm{Mo} 0$ & 0.226 & 0.166 & 0.409 \\
\hline $\mathrm{m}_{3}: \mathrm{Zn} 0+\mathrm{B} 200+$ Mo 50 & 0.249 & 0.173 & 0.423 \\
\hline $\mathrm{m}_{4}: \mathrm{Zn} 1000+\mathrm{B} 0+\mathrm{Mo} 0$ & 0.229 & 0.184 & 0.415 \\
\hline $\mathrm{m}_{5}: \mathrm{Zn} 1000+\mathrm{B} 0+\mathrm{Mo} 50$ & 0.267 & 0.212 & 0.470 \\
\hline $\mathrm{m}_{6}: \mathrm{Zn} 1000+\mathrm{B} 200+\mathrm{Mo} 0$ & 0.258 & 0.275 & 0.536 \\
\hline $\mathrm{m}_{7}: \mathrm{Zn} 1000+\mathrm{B} 200+\mathrm{Mo} 50$ & 0.276 & 0.295 & 0.637 \\
\hline S.Em. \pm & 0.00 & 0.00 & 0.01 \\
\hline C.D. at $5 \%$ & 0.01 & 0.01 & 0.02 \\
\hline \multicolumn{4}{|c|}{ Factor B : Stage of micronutrients application (S) } \\
\hline s1: At seedling stage (15 DAS) & 0.222 & 0.192 & 0.407 \\
\hline $\mathrm{s}_{2}:$ After transplanting stage $(20 \& 35$ DAT $)$ & 0.224 & 0.192 & 0.449 \\
\hline s3: At seedling stage (15 DAS) and After transplanting stage (20 \& 35 DAT) & 0.255 & 0.207 & 0.474 \\
\hline S.Em. \pm & 0.00 & 0.00 & 0.00 \\
\hline C.D. at $5 \%$ & 0.01 & 0.01 & 0.01 \\
\hline \multicolumn{4}{|l|}{ Interaction: (S x M) } \\
\hline S.Em. \pm & 0.01 & 0.01 & 0.01 \\
\hline C.D. at $5 \%$ & NS & NS & NS \\
\hline C. V. $(\%)$ & 4.23 & 4.51 & 5.15 \\
\hline
\end{tabular}




\section{Conclusion}

Thus from the present investigation it could be concluded that for successful cultivation of cabbage, micronutrient should spray at seedling stage (15 DAS) and 20 \& 35 DAT for getting good quality. Micronutrients should applied @ Zn 1000 ppm + B 200 ppm + Mo 50 ppm for same.

\section{References}

1. Cakmak I. Possible roles of zinc in protecting plant cells from damage by reactive oxygen species. New Phytologist 2000;146(2):185-205.

2. Chattopadhyay SB, Mukhopadhyay TP. Effect of foliar application of boron and molybdenum on growth and yield of cauliflower in tarai zone West Bengal. Environment and Ecology 2003;21(4):955-59.

3. Hakala C, Verma H, Hanit H. Micronutrient application and their effects on vegetable crops. Journal of Agricultural Science and Technology 2006;43(2):114120.

4. Hewitt EJ, Bolle-Jones EW. Molybdenum as a plant nutrient. The influence of molybdenum on the growth of some Brassica crops in sand culture. Journal of Horticultural Science 1952;27:245-256.

5. Jany MN, Sarker C, Mazumdar MA, Shikder MF. Effect of storage conditions on quality and shelf life of selected winter vegetables. Journal of Bangladesh Agricultural University 2008;6(2):391-400.

6. Kotecha AV, Dhruve JJ, Vihol NJ. Effect of foliar application of micronutrients and growth regulators on growth and yield of cabbage (Brasicca oleracea L. Var. capitata) cv. Golden Acre. Asian Journal of Horticulture 2011;6(2):381-384.

7. Lashkari CO, Makawana AN, Meman MA. Effect of zinc and iron on growth and yield of cauliflower (Brassica oleracea var. botrytis L.) cv. Snowball-16. The Asian Journal of Horticulture 2007;2(2):277-279.

8. Mehraj H, Taufique T, Mandal MSH, Sikder RK, Jamal Uddin AFM. Foliar Feeding of Micronutrient Mixtures on Growth and Yield of Okra (Abelmoschus esculentus). American-Eurasian Journal of Agricultural \& Environmental Science 2015;15(11):2124-2129.

9. Sadasivam, Manickam A. Biochemical methods. New age international publishers. New Delhi 1997.

10. Sainju UM, Dris R, Singh B. Mineral nutrition of tomato. Food, Agriculture and Environment 2003;1(2):176183. 